\title{
Teacher Training for Children with Autism Spectrum Disorders in Finland
}

\section{Rämä, Irene}

Springer

2019-10

Rämä , I , Pirttimaa , R , Ojala , T , Pesonen , H \& Kontu , E 2019 , Teacher Training for Children with Autism Spectrum Disorders in Finland . in X Hu \& E Kärnä (eds), Educating Students with Autism Spectrum Disorder in China and Finland. New Frontiers of Educational Research , Springer , Singapore , pp. 183-195 . https://doi.org/10.1007/978-981-13-8203-1_12

http://hdl.handle.net/10138/324058

https://doi.org/10.1007/978-981-13-8203-1_12

acceptedVersion

Downloaded from Helda, University of Helsinki institutional repository.

This is an electronic reprint of the original article.

This reprint may differ from the original in pagination and typographic detail.

Please cite the original version. 


\title{
Chapter 6
}

\subsection{Teacher Training for children with autism spectrum disorders in Finland}

Rämä, Irene

University of Helsinki, Faculty of Educational Sciences, Centre for Educational Assessment, irene.rama@ helsinki.fi ,+358503198535

Pirttimaa, Raija

University of Jyväskylä, Faculty of Education and Psychology, raija.pirttimaa@jyu.fi , +358 408053633

Ojala Terhi

University of Helsinki, Faculty of Educational Sciences, Centre for Educational Assessment, terhi.ojala@ helsinki.fi , +358504160774

Pesonen, Henri

University of Helsinki, Faculty of Educational Sciences, henri.pesonen@ helsinki.fi , +358 50 3111944

Kontu, Elina

University of Helsinki, Faculty of Educational Sciences, elina.kontu@ helsinki.fi , +358 50 3182380

\begin{abstract}
This chapter first provides a short description of the historical background and development of special education teacher training in Finland. The relationship between special education and teaching pupils with autism spectrum disorder (ASD) is covered by chronologically presenting the main events, turning points, publications, and people that have had a significant effect on the education of pupils with ASD in Finland. This is followed by a description of the organization of teacher training, in general, and the particular characteristics of teaching pupils with ASD. In the context of ASD, it is essential to examine questions concerning the link between learning as social practice and the challenges of interaction manifested in learning difficulties. The chapter ends with a description of the continuing teacher education for special education teachers in Finland.
\end{abstract}

\section{Background and development of special education teacher training}

The first schools for children with disabilities in Finland were founded for pupils diagnosed with the designations for that time: blind, deaf, and mental retardation. This development occurred in the 1800s. These facilities were boarding schools for children who were assessed to be capable of developing their skills (Kivirauma, 2015). Accordingly, the first teachers for these institutions acquired their competence via apprenticeships in these special schools. When general compulsory education in Finland started in the 1920s, there was a strong ethos of equality: boys and girls were educated and special schools for slow learners and pupils with disabilities were established (Ahonen, 2014). Gradually, the number of special schools and classes increased, though some disabled children were still excluded. 
Education for mildly mentally retarded children was arranged beginning in the 1940s, and a new need for teachers skilled in this area was recognized. The first formal special education teacher-training course was organized on the higher education level in the 1950s. Special education teacher training for children with profound or severe intellectual disability did not begin until the 1990s. Since the status of teachers has been high in Finland, it is natural that all teacher training is arranged on the university level (Kansanen, n.d.; Välijärvi, n.d.).

According to Hautamäki and Jahnukainen in Special Education Strategy (Ministry of Education, 2007), special teacher training for different groups of children with disabilities stabilized in the 1950s and was organized regularly as part of higher education studies. In the 1970s, comprehensive school reform further broadened special education, but it remained segregated; differently disabled pupils were taught in their own groups (Ministry of Education, 2007). Part-time special education (see Takala et al., 2009) started during that decade too. Schools began to employ special education teachers and special itinerant teachers to instruct and support pupils with special needs and disabilities in mainstream classes.

Special teacher training was not organized as 'disability based' at the universities until the 1990s. That is, teachers acquired niche qualifications to train children who were visually, auditory, physically, or mentally handicapped. In addition, some teacher students familiarized themselves with speech impairments, reading and writing difficulties, or socio-emotional problems. When the school and education policy began to emphasize inclusive education, 'disability-based' training weakened. More recently, teachers receive extensive training that prepares them for different positions in special education. When the concept of autism became familiar, for instance, universities began sharing information about this condition as part of the training for all teachers. Information on autism is now offered through additional courses as well.

\section{Special education and autism}

The conceptualization and presentation of autism began appearing in Finnish historical works and seminal readings in the 1960s (e.g., Donner, 1962; Valanne, 1962) but did not become more common until the 1980s (e.g., Fadjukoff \& Ikonen, 1987; Fadjukoff, 1988; Ikonen, 1998; Timonen, 1991; Vinni, 1987; Vinni \& Timonen, 1988). The continuous professional and pedagogical focus on autism that began in the 1980s (Fadjukoff \& Ikonen, 1987) changed the conditions for rehabilitating and educating children with autism.

A turning point in educating children with autism in Finland took place in 1990 when Finnish researchers and other field professionals started organizing continuing education courses for teachers of pupils with ASD at the University of Jyväskylä (Ikonen, 1998; Kerola et al., 2009). In the same year, Lovaas visited Helsinki and gave a seminar about language and communication practices for children with mental disabilities and autism (Ikonen, 1998). In addition, the first separate kindergarten classes for children with autism were established in 1991 (Kerola et al., 2009). Researchers translated books by Lovaas (1992) and Grandin and Scariano (1986) into Finnish, and television shows presented discussion panels about autism, teaching, and parenting in 1992 (Ikonen, 1998). Three years later, in 1995, more books about autism were published in Finnish, and the first official video (Finnish National Board of Education, 1995) for educational purposes was released. In 1972, Schopler started developing a program called the Treatment and Education of Autistic and related Communicationhandicapped Children (TEACCH). In 1997, all TEACCH materials were translated into 
Finnish (Ikonen, 1998; Kerola, 1997). Assessment tools such as the CARS and PEP-R had been translated into Finnish in 1993 and 1994 (Kerola, 2009).

TEACCH made frequent developmental assessments possible with the help of these assessment tools. TEACCH awareness throughout Finland led to curriculum development, resulting in the inclusion of a curriculum for pupils with autism in the Finnish core curriculum in 1999 (Virtanen, 2000), the same year that the first autism classes were officially established in Finland. One year later, in 2000, the Finnish National Board of Education published a curriculum booklet that explained the structured teaching methods and TEACCH approaches and taught teachers how to utilize them in autism classes (Virtanen, 2000). Literature about Asperger's Syndrome, DVDs, and other educational documents about ASD have since been translated into Finnish.

\section{Teacher training in general in Finland}

The main ethos in teacher education, in general, as well as Special Needs Education (SNE) teachers' training in particular, is to train individuals who are pedagogically dynamic, flexible, and capable of adapting to various and changing situations. Teacher education guides student teachers to be proactive, active, and social. They are encouraged to follow changes in society and to be future-oriented. Pedagogical expertise is manifested in teaching that stresses the participation of all pupils, the well-being of pupils, and human rights. The nationwide basis for curricula includes clearly stated values that are followed in the training of SNE teacher students to help them develop high quality pedagogical expertise.

Teacher education is founded on solid scientific grounds. It is expected to use up-todate, research-based knowledge when training future teachers. Teacher education departments are part of universities, therefore, they are responsible for research, too. An ideal teacher is a researcher who is motivated to oversee his or her own professional development. Teacher training also aims to promote active citizens who network and participate in all parts of society (see Kumpulainen \& Renshaw, 2007). Teachers are seen to hold positions as positive agents for change in society. Teacher education, at its best, is training for the future, thus, it does not tell a student how things are, but focuses on goals for tomorrow.

Training programs include contents that guide students to master issues linked with society and ethics. They learn about the theoretical concepts like learning, inclusive education, diagnosis, and disability. Programs include information on the historical development of special education. Students learn how to assess the accessibility of various learning environments and study the emancipatory and critical aspects of teaching.

\section{Special teacher training today}

SNE teachers are trained today at universities. During five years of studies, they earn a Master's degree. Usually, the major subject they study is special education, and pedagogical training in special needs education is integrated into the Master's degree curriculum. The subject special education is one of the disciplines that is connected with other disciplines, such as general education, social studies, medicine, and psychology. Many special education teachers first earn a certificate for classroom teaching (with a major in education or psychology) and, after a one-year university course, qualify for SNE teaching. Students 
entering the SNE teacher studies program must pass an aptitude test in which their motivation, academic skills, and suitability are measured.

In early childhood settings, SNE teachers work with children under seven years of age. They usually have a Bachelor's degree in education, early childhood education, or special education, and after completing these studies, they can enter the one-year SNE teacher course at a university. Students who hold an applicable Bachelor's degree or an applicable vocational diploma from a polytechnic are also eligible to enter a university for a one one-year SNE teacher course. They will have limited eligibility in their teaching duties as they are qualified only to teach children with intellectual disabilities.

\section{The characteristics of Autism Spectrum Disorder and teaching}

When an SNE student teacher focuses on autism in his or her studies, the main issue is interaction and communication. They learn how individual behaviors and environmental expectations meet in the context of autism. Various individual hyper- and/or hypo-sensory issues are explored, as are the individual and autism-linked special and intensive interests, which some people with autism may have.

\section{Learning as interaction and social practice}

In SNE training, learning is conceived in line with the theory of pragmatic constructivism (e.g. see Rauste-von Wright et al., 2003; Resnick, 1989; Resnick \& Hall, 1998; von Wright, 2000). According to that theory, human beings are by nature active and intentional doers who seek stimulation and feedback on their actions and selves in the world. It is typical for humans to scan continuously the environment they are in, and pick up substances, ingredients, and materials that guide their actions and thoughts or thinking. In other words, people store up and interpret new information and build up a constantly analyzed and enriched picture of the physical and social world in which they live (Rauste-von Wright et al., 2003; Resnick 1989; Resnick and Williams Hall 1998; von Wright 2000). William T. Hanks articulates that "learning is a way of being in the social world" (Hanks, 1991, p. 24) and the point is in the opportunity to develop and grow through participation (Hanks, 1991; see also Lave \& Wenger, 1991).

The goals linked to social behavior, interaction, and communication should guide the pedagogical actions of a teacher, but the instrumental nature of these goals over academic goals might cause some problems if a teacher does not recognize the relationship between these goals and the process of learning. Accordingly, the educational perspective for SNE teachers stresses interaction, communication, social life, and meeting special needs, because these features overall affect and are present in the learning processes. It is emphasized that everybody is capable of interacting and everybody is constantly interacting when with others. This viewpoint reflects the turn from the disability-centered perspective to the more positive perspective that pays more attention to a person's individual strengths (see e.g. Donaldson \& Ko, 2010; Seligman et al., 2009; Seligman \& Csíkszentmihályi, 2000). Therefore, all teacher training aims to transfer the principles of the positive pedagogy to the social and cultural construction of well-being and learning (see also Vygotsky, 1978; Wertsch et al., 1995). The meaning of social and communal relationships for learning processes is also stressed in teacher training (van Huizen et al., 2005; Wenger, 1998). 
Knowledge of the development of language is an important perspective regarding interaction, i.e. interaction, communication, and social relationships are tightly linked to the development of language and its practical usage. Challenges in verbal communication in ASD are naturally a part of SNE teacher training, but study entities connected to interactional activities in ASD also include courses on non-verbal aspects of communication. This is because of the wide range of communicational means typical for ASD. For example, people with ASD might use pictures, signs, facial expressions, gestures, postures, movements, actions, vocalizations, or other utterances that consist of tones, accents, and carry meanings besides words and speech. Keeping silent, taking pauses, or using other 'non-actions' can also be used as communicative means when communicating with people with ASD.

No matter the type of communication or interaction used, it is essential that counterparts interpret their interactional messages in the same way. This requires a common 'language,' which in the context of special education, usually means that the teacher must adjust or adapt his or her communication to achieve this common 'language.' Therefore, an essential part of the Finnish SNE teacher training is communicative skills and the development of those skills in teacher students. Providing conversational lessons, using interactive teaching methods, favoring study groups, and offering training periods in an actual school context are examples of focusing on communication and interaction.

The focus on social and communicative skills is also based on the fact that, in ASD, it is typical to make contact with other people in a very distinctive manner. For this reason, the teacher's ability to get into contact with pupils, understanding the individual characteristics of pupils, and the ability to adapt to the interactional level of a pupil's communication are considered teacher strengths. These skills require profound conceptual understanding of social interaction and communication and sensitive relating and/or a sensitive relationship with the pupils. The meaning of teaching arises from the pedagogical interaction, which is conceived as interactive actions between the teacher and the pupils. The aim of these actions is to make possible and to ensure the learning of the pupils in line with certain goals. The teacher is regarded as an enabler, a supporter, or a facilitator of communication, not as a transferor of knowledge. The pedagogical activity of the teacher is supposed to balance the asymmetry of interaction, which rises from the differences in the skills and knowledge of the participants.

The quality of pedagogical interaction is emphasized as well if the participants' interactional skills are very uneven like when teaching pupils with ASD. It is possible to use high-class pedagogic interaction to prevent frustrations linked to not-so-successful interaction. Preventing these frustrations directly affects learning possibilities. However, it must be accepted that when educating or working with persons with ASD or with other people needing special support, the teaching must be individually customized depending on the performance and qualities of the person. In practice, it is not possible to use any readymade teaching packages or syllabi, and general teaching tips cannot be distributed or delivered in the same way as in general education. Therefore, the basic principles and values concerning teaching and learning form a substantial part of the structure in special education and directs teaching in line with these principles and values. This is why teacher students must learn to reflect on their own thoughts and opinions concerning teaching and learning. Different pedagogic or rehabilitative methods and instruments are available, but quite often these must be adjusted to fit individual needs. 
In SNE teacher training, different aspects of learner-specific qualities are handled because these aspects might have an impact when planning teaching and the linked learning processes. For example, a learner's motivation, interests, former knowledge and experiences, personal learning strategies, learning potential, ability to adapt, creativity, genetic inheritance, along with the relationship with the teacher affect the learning of the pupil. The teacher can use the strengths in ASD, such as fixations on certain topics, to develop and maintain the motivation of the pupil. The teacher can also directly affect the relationship between the teacher and the pupil.

A certain ASD trait, abnormal reaction to different sensory stimuli, is also considered in SNE teacher training. In developmental disabilities, it is usual that people adjust to sensory stimuli considerably slower than in general. In terms of learning, this means that a person's brains react to familiar stimuli as if they were continuously new. In practice, learning is slower and requires more repetition. On the other hand, although repetition and recognizing similarities are the foundation of learning, situations that remain continuously the same do not enable the learning of new things; variation is essential. In the case of ASD, neural underand overreaction might cause affections, for example, exceptionally strong sensations. These sensations, in turn, may cause different self-protective reactions in the pupil, such as retreating, closing oneself in, or outbursts of rage. A teacher must be able to prevent the formation of these reactions in his or her teaching activities and strive to create the potential for a positive learning atmosphere for all pupils. Familiarity with the pupil is one of the most important factors when designing individualized education especially with ASD, where personal differences in functioning can be significant and ability profiles can be uneven also within the individual ability areas.

\section{Learning difficulties}

Teacher education also includes information on an extensive array of learning difficulties. Different learning difficulties and their causes are introduced, and information on means and instruments to handle these difficulties are provided to enhance pupils' learning. It is stressed that the main features appearing in ASD, like challenges in interaction, communication, and social behavior, are comprehensively present in learning processes. In other words, the difficulties in these areas are immediately reflected in learning. However, the reason for learning difficulties might be hard to find because learning depends on so many successful (or not so successful) procedures.

Reasons for learning difficulties may arise from all areas that affect learning and dealing with knowledge, for example, areas like attention, memory, intelligence, socioemotional reasoning, motor-sensory functions, basic visual functions, functions linked to language, and reactivity. Inaccurate or deficient processing of these functions may cause learning difficulties, which may be revealed in academic skills like reading, writing, or mathematics.

An important and integral part of the special needs teacher's professionality is to detect learning difficulties. Therefore, it is natural that SNE training includes content that focuses on detecting needs for support and assessing these needs to promote students' learning. For this reason, a special needs teacher must have profound knowledge of assessment.

Along with assessing the support needed, the teacher must be able to assess the effects of different intervention programs to a pupil's development and learning. The assessment 
should be versatile and focus comprehensively on the different factors of cognitive, motor, socio-emotional, and communicative development. One part of being a professional teacher is to be able to use, modify, and create measures and tests for assessment. It is important to know how to interpret the information gained from tests and to plan pedagogic activities based on this information. This professionality involves the ability to draw conclusions and make decisions based on relevant information and acts that promote a pupil's learning in line with the learning goals.

Pupils with ASD often study according to an activity-area-based curriculum. Knowing and learning is, in such cases, assessed by means of activity areas, and the assessment focuses on achieving the pupil's goals. The assessment is always verbal (written, not oral). If an activity area includes goals or contents for separate subjects, it is possible to describe the assessment of these subjects as part of the verbal assessment or in an attached appendix. If the pupil studies any subjects in line with a general curriculum, it is also possible to give numeric assessments of those subjects.

In Finnish special education training, studies are not diagnosis-based, that is, there are no training entities for teaching pupils with ASD. Despite this, special teacher training consists of many different course totalities that include topics linked to ASD or topics adapted for teaching pupils with ASD. For example, there are plentiful courses including themes on interaction, communication, behavior, and sensory functions.

Typical contents and entities concerning ASD in Finnish SNE teacher training are listed in Figure 1. 


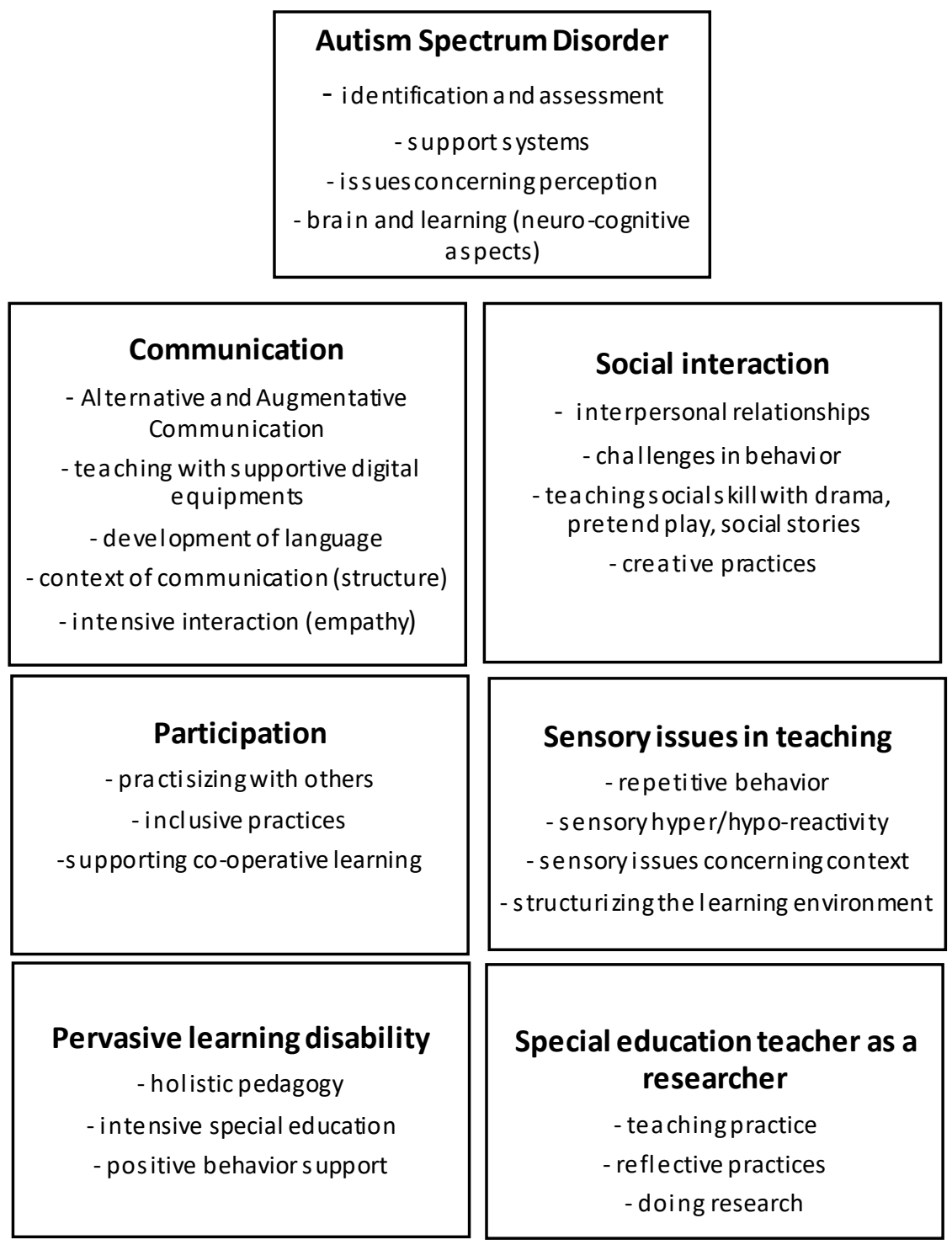

Fig. 6.2.1 Typical contents and entities concerning ASD in Finnish SNE teacher training

\section{Teaching practice}

Teaching practice is an essential part of teacher education. A qualified and experienced special teacher guides the teaching practice of students. It is possible that an SNE teacher student can practice under the guidance of his or her mentor. At the same time, students can apply their theoretical knowledge in practice. An SNE teacher has to know all the standards of education, for example, basic legislation and the national core curriculum, as well as national and local government and school teaching guide documents. During teaching practices teacher trainees are exposed to the preparation of pedagogical documents and practicing work in multi-disciplinary work communities. 
Encounters with parents, teaching design and implementation, as well as pupil welfare are also key themes related to special needs skills. Along with the non-disclosure agreement, responsibility issues and a code of ethics are themes that the students exercise during their practicum. Teaching practice can be carried out in early childhood education units where the children are 0-5 years of age, or in pre-primary education for children 6-16 years of age, or vocational education, or high school.

\section{Continuing teacher education}

Teachers are recognized as keys to quality in education. At most levels of education, teachers are required to participate in in-service training at least three days every year as part of their salary agreement. Finnish teachers consider in-service training to be a privilege and, therefore, participate actively (National Board of Finland, 2016). Special educators seem to be one of the most active groups of teachers $(80 \%)$ that participate in-service training (Kangasniemi et al., 2014).

Different providers, for example universities, summer universities, associations, or private companies, offer in-service training. The state funds in-service training programs, which means there are no participation fees. Education providers can also apply for funding to improve the professional competence of their teaching personnel. Special educators have been in-service trained as part of nationwide long-term development programs since 1997. The focus and main goal of these programs is inclusive education. (Hautamäki \& Hilasvuori, 2015, 20-21; Kokko et al., 2014, 7).

The state provides funds primarily in areas important for implementing education policy and reforms. The aim of continuing education is to update and renew special educators' professional skills and to develop the skills that will be needed in the educational profession in the future (Jokinen et al. 2014, 43). There are many different ways to organize continuing education, for example, seminars or conferences or gathering together and learning co-operatively, or distance learning using social media.

One of the most important issues is that teachers are given the possibility to share their thoughts, knowledge, and knowhow with each other and create peer-to-peer networks to ensure the professional competence required of the profession (Hämäläinen et al., 2015). Based on recent research findings, it seems that teachers hope for and need most complementary training of children's behavioral and emotional disorders (Kokko et al., 2014, 50). Special educators, like other teachers as well, update their profession by reading books and research on education and teaching. In addition, educational literature often is acquired by schools.

\section{References}

Ahonen, S. (2014). Yhteinen koulu tasa-arvoa vai tasapäisyyttä. [School for all - equality or not]. Tampere: Vastapaino.

Donaldson, S. I., \& Ko, I. (2010). Positive organizational psychology, behavior, and scholarship: A review of emerging literature and evidence base. The Journal of Positive Psychology, 5(3): 177-191.

Donner, M. (1962). Vajaakykyiset lapset [Incapacitated children]. In N. Hallman, K. Pakkala, 
\& P. Thuneberg (Eds.), Terve ja sairas lapsi [Healthy and sick child] (pp. 531-552). Porvoo: WSOY.

Fadjukoff, P. (1988). Autismikäsitteen kehittyminen Suomessa [Development of autism concept in Finland]. Master's thesis. Jyväskylä: University of Jyväskylä.

Fadjukoff, P., \& Ikonen, O. (1987). Kehitysvammainen autisti opetuksen näkökulmasta. [A mentally handicapped autistic child from the viewpoint of teaching]. Kasvatustieteiden tutkimuslaitoksen julkaisusarja B 12/87 [Institute for Educational Research Publication Series B 12/87]. Jyväskylä: University of Jyväskylä.

Finnish National Board of Education (Producer). (1995). Autismi. [Autism]. [VHS].

Finnish National Board of Education (2016). Teacher education. Retrieved from http://www.oph.fi/english/education_system/teacher_education

Grandin, T., \& Scariano, M. M. (1986). Emergence: Labeled Autistic. Novato: Arena Press. Hanks, W. T. (1991). Introduction. In J. Lave, \& E. Wenger, Situated learning: Legitimate peripheral participation (pp. 21-24). Cambridge: Cambridge University Press.

Hautamäki, J., \& Hilasvuori, T. (2015). Perusopetuslain erityisopetusta koskevat vuoden 2010 muutokset vïmeisimpänä vaiheena peruskoulun kehitystä [The changes made in 2010 into Basic Education Act concerning special education as the last phase of the development of comprehensive school system]. In M. Jahnukainen, E. Kontu, H. Thuneberg, \& M.-P. Vainikainen (Eds.), Erityisopetuksesta oppimisen ja koulunkäynnin tukeen [From special education to supporting learning and school] (pp. 15-24). Jyväskylä: Jyväskylän yliopistopaino.

van Huizen, P., van Oers, B., \& Wubbels, T. (2005). A Vygotskian perspective on teacher education. Journal of Curriculum Studies, 37(3), 267-290.

Hämäläinen, K., Hämäläinen, K., \& Kangasniemi, J. (2015). Paths to Continuing Professional Development. The challenges and future of state-funded professional development of education personnel. http:/www.minedu.fi/OPM/Julkaisut/2015/osaamisen_kehittaminen.html?lang=en. Accessed 9 May 2017.

Ikonen, O. (1998). Autismi. Teoriasta käytäntöön [Autism. From theory to practice]. Jyväskylä: Atena.

Jokinen, H., Taajamo, M., \& Välijärvi, J. (Eds.) (2014). Pedagoginen asiantuntijuus liikkeessä ja muutoksessa - huomisen haasteita. [Pedagogical expertise in transition: challenges of tomorrow]. https://ktl.jyu.fi/julkaisut/julkaisuluettelo/julkaisut/2014/D114.pdf_. Accessed 9 May 2017.

Kangasniemi, J., Hämäläinen, K., \& Kyrö, M. (2014). Opettajien osallistuminen jatko- ja täydennyskoulutukseen, asiantuntija vaihtoon sekä työelämäjaksoille [Teacher participation on continuing teacher practices, expertise change and work practices]. In Opettajat Suomessa 2013. [Teachers in Finland 2013] (pp. 144-155). Koulutuksen seurantaraportit 2014:8 [Reports on monitoring education 2014:8]. Tampere: Suomen yliopistopaino Oy, http//www.oph.fi/download/156282_opettajat_suomessa_2013.pdf. Accessed 9 May 2017.

Kansanen, P. (n.d.) Teacher Education in Finland: Current Models and New Developments. http://www.helsinki.fi/ pkansane/Cepes.pdf. Accessed 9 May 2017.

Kerola, K. (1997). Strukturoitu opetus autistisesti käyttäytyvien lasten perheperustaisessa varhaiskuntoutuksessa. Akiva-projektin alkuvaiheet ja kolmen vuoden seuranta 
[Structured teaching in family-based rehabilitation for children with autism. Early stages of the Akiva-project and a three-year follow-up study]. Joensuun yliopiston kasvatustieteellisiä julkaisuja 39 [University of Joensuu. Publications 39]. Joensuu: University of Joensuu.

Kerola, K., Kujanpää, S., \& Timonen, T. (2009). Autismin kirjo ja kuntoutus [Autism Spectrum Disorders and Rehabilitation]. Juva: WS Bookwell.

Kivirauma, J. (2015). Erityisopetuksen historialliset kehityslinjat. [The historical trends of special education] In S. Moberg, J. Hautamäki, J. Kivirauma, U. Lahtinen, H. Savolainen, \& S. Vehmas (Eds.), Erityispedagogiikan perusteet [Basics of special education] (pp. 25-41). Jyväskylä: PS-kustannus.

Kokko, T., Pesonen, H., Polet, J., Kontu, E., Ojala, T., \& Pirttimaa, R. (2014). Erityinen tuki perusopetuksen oppilaille, joilla tuen tarpeen taustalla on vakavia psyykkisiä ongelmia, kehitysvamma-taiautismin kirjon diagnoosi [Special support for pupils with socialemotional problems, profound or severe disabilities, or autism]. VETURI-hankkeen kartoitus 2013 [VETURI-project survey results 2013]. Jyväskylä: Universities of Jyväskylä and Helsinki.

Kumpulainen, K., \& Renshaw, P. (2007). Culture and learning. A special theme issue. International Journal of Educational Research, 46(3-4), 109-115.

Lave, J., \& Wenger, E. (1991). Situated learning: Legitimate peripheral participation. Cambridge: Cambridge University Press.

Lovaas, I. (1992). Kehitysvammaisten lasten opettaminen: minä-kirja [Teaching Children with Developmental Disabilities: All About Me Book]. Helsinki: Kehitysvammaliitto, oppimateriaalikeskus.

Ministry of Education (2007). Special education strategy. Reports of the Ministry of Education, Finland 2007:47, 17-22. Helsinki: Helsinki University Press.

Rauste-von Wright, M., von Wright, J., \& Soini, T. (2003). Oppiminen ja koulutus. [Learning and education]. Helsinki: Bookwell.

Resnick, L. B. (1989). Introduction. In Knowing, learning, and instruction: Essays in honor of Robert Glaser, (Ed. L. B. Resnick) (pp. 1-24). Hillsdale, NJ: Erlbaum.

Resnick, L. B., \& Hall, M. W. (1998). Learning organizations for sustainable education reform. Daedalus, 127(4), 89-118.

Seligman, E. P., \& Csikszentmihályi, M. (2000). Positive psychology: An introduction. American Psychologist 55(1), 5-14.

Seligman, E. P., Ernst, R. M., Gillham, J., Reivich, K., \& Linkins, M. (2009). Positive education: Positive psychology and classroom interventions. Oxford Review of Education, 35(3), 293-311.

Takala, M., Pirttimaa, R., \& Törmänen, M. (2009). Inclusive special education: the role of special education teachers in Finland. British Journal of Special Education, 36(3), 162173.

Taajamo, M.( 2014). Erilaisia näkökulmia opettajan työn kehittämiseen. In H. Jokinen, M. Taajamo, \& J. Välijärvi (Eds.), Pedagoginen asiantuntijuus liikkeessä ja muutoksessa-huomisen haasteita [Pedagogical expertise moving and changing challenges of the future] (pp. 67-78). Koulutuksen tutkimuslaitos [Institute of Educational Research]. Jyväskylä: University of Jyväskylä. https://ktl.jyu.fi/julkaisut/julkaisuluettelo/julkaisut/2014/D114.pdf_. Accessed 9 May 2017.

Timonen, T. (1991). Autismi: käyttäytymisanalyyttinen näkökulma [Autism: behavioral 
analytic point of view]. Doctoral dissertation. Helsinki: Kehitysvammaliitto.

Valanne, E. (1962). Psyykkiset häiriöt [Mental disorders]. In N. Hallman, K. Pakkala, \& P. Thuneberg (Eds.), Terve ja sairas lapsi [Healthy and sick child] (pp. 501530). Porvoo: WSOY.

Vinni, I. (1987). Varhaislapsuuden autismin esiintyvyys Suomessa [Prevalence of autism in early childhood in Finland]. Master's thesis. Joensuu: University of Joensuu.

Vinni, I., \& Timonen, T. (1988). Autismi Suomessa. [Autism in Finland]. Valtakunnallisen tutkimus- ja kokeiluyksikön julkaisuja 48/1988. [A nationwide research and intervention publication 48/1988]. Helsinki: Kehitysvammaliitto.

Virtanen, P. (Ed.) (2000). Autististen lasten opettaminen [Teaching children with autism]. Helsinki: Hakapaino Oy.

Vygotsky, L. (1978). Mind in society: The development of higher mental processes. Cambridge, MA: Harvard University Press.

Välijärvi, J. (n.d.). The history and present of the Finnish education system. Seminar paper. Sino-Finnish seminar on education systems, Shanghai. http://cice.shnu.edu.cn/LinkClick.aspx?fileticket=U5rzr6FYThQ=. Accessed 9 May 2017.

Wenger, E. (1998). Communities of practice: Learning, meaning and identity. Cambridge: Cambridge University Press.

Wertsch, J., del Rio, P., \& Alvarez, A. (Eds.) (1995). Sociocultural studies of mind. New York, NY: Cambridge University Press.

von Wright, J. (2000). On the function of learning. Conference paper presented in Innovations of Higher Education 2000. Helsinki. 